\title{
Advances in Health Promotion for People with Disabilities and the Laws of Brazil
}

\author{
Luciana Vieira de Carvalho, Aline Cruz Esmeraldo Áfio, Jânio Cavalcanti Rodrigues Jr., \\ Cristiana Brasil de Almeida Rebouças, Lorita Marlena Freitag Pagliuca* \\ Department of Nursing, Universidade Federal do Ceará, Fortaleza, Brazil \\ Email: ${ }^{*}$ pagliuca@ufc.br
}

Received 23 July 2014; revised 8 September 2014; accepted 25 September 2014

Copyright (C) 2014 by authors and Scientific Research Publishing Inc.

This work is licensed under the Creative Commons Attribution International License (CC BY). http://creativecommons.org/licenses/by/4.0/

c) (i) Open Access

\begin{abstract}
Brazilian laws guarantee the protection to the rights of the citizenship of people with disabilities and their participation in various social sectors which influence health promotion. One aimed at reflecting about the health promotion actions contemplated in Brazilian laws directed to people with physical, hearing and visual disabilities. Through the website of the National Secretariat for the Promotion of the Rights of People with Disabilities, one selected 14 laws whose content was articulated to the Health Promotion Charts in the process of discussion. The laws had as their main objective, the accessibility of people with disabilities to urban spaces, health, income, education, transportation and leisure, i.e. to public services that are essential for the establishment of health. It is concluded that there was a progress in the elaboration of laws that guarantee the rights and integration of this population. However, it is observed that the non-compliance of the laws makes the promotion of health impossible.
\end{abstract}

\section{Keywords}

People with Disabilities, Health Promotion, Legislation

\section{Introduction}

The concept of health promotion as the process of enabling the community to work on the improvement of their quality of life was defined in the First International Conference on Health Promotion. During this event one also set up the prerequisites for health, with emphasis on the factors involved in individual and collective aspects, on the government and social empowerment to practice this concept, and five action fields of health promotion were delimited, namely: the development of healthy public policies, strengthening of community action, crea-

\footnotetext{
${ }^{*}$ Corresponding author.
}

How to cite this paper: de Carvalho, L.V., Áfio, A.C.E., Rodrigues Jr., J.C., de Almeida Rebouças, C.B. and Pagliuca, L.M.F. (2014) Advances in Health Promotion for People with Disabilities and the Laws of Brazil. Health, 6, $2365-2374$. 
tion of health spaces, development of personal skills and reorientation of health services [1].

The conceptions of health promotion emerged in 1974 through a movement in Canada, which originated the Lalonde Report. This document discussed the reorientation of the health system, recognizing the power that public policies had in the achievement of health. Although the motivation that emerged for the creation of this document was primarily economic, with the goal of the reducing rising costs of medical care, it was the framework for the study of health promotion [2], and boosted notable movements for a change of paradigm that involved the topic in question. Health, which before was understood as the absence of disease, based on the biomedical model, began to be understood as a complete physical, mental and social well-being, and to achieve it, a balance in all aspects of life is necessary.

Contributions to the new concept of health in Brazil, emerged from the Federal Constitution of 1988, are consolidated with Law 8080/90 that determines the conditions to promote, protect and restore health, such as universality, comprehensiveness, preservation of autonomy, equality of health care, right to information, among others [3]. A major challenge is to guarantee the right of everyone to access to health; among them people with disabilities deserve special attention because they are socially excluded population groups.

It is estimated that in Brazil there are approximately 46 million (23.9\%) people with disabilities, out of those (18.50\%) with visual impairment; motor (7\%); hearing (5.10\%) and mental $(1.40 \%)$ [4]. These people have greater exposure to risk factors such as sedentary lifestyle, gain of weight, poor dietary habits, low socioeconomic conditions, poor access to education and health services, suggesting a deficit of information. Thus, they become more vulnerable to developing chronic diseases, requiring special attention to health due to the peculiarities of their disability [5].

Social movements started to demand equal opportunities and achievements. The development of the discussions enabled a process of recognition of governments and society on the theme that culminated in the creation of laws aimed at protecting the rights of citizenship for this population [6].

Laws guarantee rights and duties to everyone, and institute interventions in various sectors of society. Recognizing the legislation that establishes public policies that affect the social organization is paramount to promote the health of people with disabilities. In Brazil, there is a legal framework aimed at this population and reflecting about actions present in them is relevant to fulfill and meet gaps in its composition. Therefore, this study was based on the following question: what are the actions of health promotion that are advocated by Brazilian laws for people with disabilities?

Given the above, this study aims to evaluate the actions of health promotion contemplated by Brazilian laws for people with physical, hearing and visual impairment.

\section{Method}

Descriptive study of documentary character about the actions of health promotion which are present in the Brazilian legislation directed to people with disabilities. As the corpus of the study, one considered the laws available on the National Secretariat for the Promotion of the Rights of People with Disabilities [7], of the Federal Government of Brazil, and the Health Promotion Charts.

It was adopted as inclusion criteria the laws formulated from the year 1988 on, when the Brazilian Constitution was promulgated, considered a landmark for health, those placed in the context of health promotion, and aimed to physical, hearing and visual disabilities. Laws aimed at mental disabilities were excluded. These groups have in common the difficult access in communication and or mobility, but it has preserved cognitive abilities, well-justified, the exclusion of people with mental disabilities.

One used the notes of the study as a methodological framework [8], which establishes two assessment phases, namely pre-analysis and analysis. The first involves collecting information from these documents, in which one applied the five dimensions recommended: historical context; authors; authenticity and reliability; nature of the text; key concepts and the internal logic of the text. To consolidate these data, one prepared a roadmap consisting of five items: 1) number of the law, 2) year of sanction, 3) established dispositions, 4) health conditioning factor and 5) actions of health promotion. The second deals with the grouping of the elements listed for interpretation and subsequent questioning, which were subjected to qualitative analysis and had as support the principles and guidelines of the Health Promotion Charts. The second step, qualitative analysis, led the reading and the organization of material selected for their willingness to categories that had to support the principles and guidelines of the Letters of Health Promotion, thereby respecting the laws were grouped the main 
aspect covered.

\section{Results}

One found 32 laws, and 12 were selected for presenting contributions to health promotion for people with disabilities. These were categorized according to the proposals contained in the Health Promotion Charts that determine the factors that influence health and quality of life [1]. In this context, one illustrates the results into five categories, namely: urban mobility, health services, education, employment and income, and leisure (Table 1).

The Federal Constitution of 1988 and Law 8.080/90 establishing the principles of health that contributed to reformulating public policy, whose function is to guide the resolution of specifics problems in many social sectors in particular, recognized as crucial to the promotion of health problems. Thus, the programs creation is essential for performing actions stipulated by public policies (Table 2).

Health principles such as universality, which ensures access to health care for all citizens access to health care for all citizens; completeness, establishes the right of everyone to totally care; equality, treats everyone equally; autonomy, offers opportunity for choice and right to information, enables for self-health, brought advances in the health of everyone, including people with disabilities, since they allow this population to usufruct the activities and services of this sector [3].

Table 1. Exposure of categories constructed from the action of health promotion stipulated by law. Fortaleza, CE, Brazil.

\begin{tabular}{|c|c|c|c|}
\hline Category & Law/year & Disposition & Action to promote health \\
\hline \multirow{6}{*}{$\begin{array}{l}\text { Urban } \\
\text { mobility }\end{array}$} & $8899 / 94$ & Free pass in interstate public transportation. & Guarantee of free circulation. \\
\hline & $10,048 / 00$ & Prioritizes care services. & Offer of safe goods and services. \\
\hline & $10,098 / 00$ & $\begin{array}{l}\text { Architectural planning of urban spaces and equipment } \\
\text { for people with disabilities. }\end{array}$ & $\begin{array}{l}\text { Access to the places quickly } \\
\text { and securely. }\end{array}$ \\
\hline & $10,226 / 01$ & $\begin{array}{l}\text { Voting places easily accessible to people with } \\
\text { physical disabilities. }\end{array}$ & Defending the rights of citizenship. \\
\hline & $11,126 / 05$ & Guide dog. & Guarantee of autonomy. \\
\hline & $12,587 / 12$ & National policy on urban mobility. & Improvement of access and mobility. \\
\hline \multirow{5}{*}{ Education } & $7853 / 89$ & National policy for integration of people with disabilities. & Inclusion of special education. \\
\hline & $10,436 / 02$ & $\begin{array}{l}\text { Includes sign language in speech therapy and } \\
\text { teaching curricula. }\end{array}$ & Contribution to education. \\
\hline & $10,753 / 03$ & Increases the number of books printed in Braille. & Access to information. \\
\hline & $10,845 / 04$ & $\begin{array}{l}\text { Complementation program to specialized } \\
\text { educational services. }\end{array}$ & Equity in education. \\
\hline & $12,319 / 10$ & $\begin{array}{l}\text { Regulates the profession of translator and interpreter of } \\
\text { sign language. }\end{array}$ & Inclusion in the school environment. \\
\hline $\begin{array}{l}\text { Work and } \\
\text { income }\end{array}$ & $7853 / 89$ & $\begin{array}{l}\text { National policy for the integration of people } \\
\text { with disabilities. }\end{array}$ & Equity in the labor market. \\
\hline \multirow[t]{4}{*}{ Health services } & $7853 / 89$ & National policy for the integration of people with disabilities. & Favorable spaces to health. \\
\hline & $10,098 / 00$ & Makes available spaces reserved for people with disabilities. & $\begin{array}{l}\text { Access to services that } \\
\text { promote health. }\end{array}$ \\
\hline & & & \\
\hline & $11,982 / 09$ & Adaptation of rides in amusement parks. & $\begin{array}{l}\text { Socialization, physical, psychological } \\
\text { and intellectual training. }\end{array}$ \\
\hline
\end{tabular}


Table 2. Exposure of categories based on the relationship between law, public policies and programs. Fortaleza, CE, Brazil.

\begin{tabular}{|c|c|c|c|}
\hline Categories & Federal Constitution-Law 8080/90 & Ministries/public policy & Programs \\
\hline Mobility & Universality & Cities_urbans policies. & $\begin{array}{l}\text { Adapt structure of public transport; } \\
\text { Architecture planning of urban facilities. }\end{array}$ \\
\hline Education & Completeness & Education-policies in education. & Train professionals to inclusive education. \\
\hline Work and income & Autonomy & $\begin{array}{l}\text { Labor and employment-policies of } \\
\text { work, employment and income. }\end{array}$ & Afford vacancy and working conditions. \\
\hline Health & Rights of information & Health—health policies. & Ensure access and adequate treatment. \\
\hline Leisure & & $\begin{array}{l}\text { Culture and sports—policies } \\
\text { of sport and leisure. }\end{array}$ & Reserve spaces; adapt leisure facilities. \\
\hline
\end{tabular}

\section{Discussion}

Obeying the order of Table 1 and Table 2, the categories will be explained with the corresponding law and the approach aimed at the context of the Health Promotion Charts.

Accessibility refers to a condition inserted in the environment or in the communication that provides a secure and autonomous participation of people in public and private areas, use of equipment and urban furniture, enabling greater social inclusion and improved quality of life [9]. Enabling access to urban areas is a measure that respects the right of free movement of people with disabilities, allowing them to take advantage of public services that are indispensable for their development.

Public transportation, one of the most important means of transportation of the population, is responsible for integrating people to different environments, therefore, it must be accessible to the mobility of everyone. It is through the free circulation that people move to their destinations and maintain social relations, and they are of paramount importance for the achievement of citizenship and improvement of their quality of life. In the Health Promotion Charts, it is assigned to all the sectors, including transportation, the responsibility to contribute to the achievement of health. Each sector should ensure the supply of safe goods and services, enjoyable and equitable to everyone [1]. In this sense, the public transportation system must adapt its structure in order to make it available to everyone, since the reduction of barriers allows a greater access to health promoting environments [10].

The inclusion of this segment of the population in transportation services is guaranteed by laws that, respectively, give free pass in interstate public transportation to those with proven lack of conditions, and establish the production of adapted vehicles and reservation of seats with the proper identification in public transportation.

Although the legislation makes it compulsory to change the public transportation in order to offer equality to everyone in the access to urban spaces, it is highlights the failure on legal execution of transportation services in serve the legislation, since a reduced amount of adapted vehicles is available in the cities. This fact corroborates a study that evaluated the reasons associated with poor access to health services, confirming that due to the lack of private transportation, these people use public transportation, which do not meet the demand of users because many were not properly adapted [10].

It is worth noting that the limited mobility in urban spaces encountered by people with disabilities is not limited to transportation, it also includes the conditions of infrastructure of public and private places, which are often inappropriate for these people's access.

It is observed, in the law enacted by the Brazilian National Congress, the basic precepts to promote the accessibility to urban spaces and equipment, in this document one stresses the importance of the architectural planning of facilities in order to ensure the right of everyone to access and to a rapid and safe mobilization.

Faced with questions about accessibility and citizenship, one emphasizes the importance of the law that guides the choice of the voting place that can offer easy access to people with disabilities. So, they will be able to go to the voting place that have accessible structures and vote in the representative who defends the rights of citizenship of the population group which they belong to.

A strategy used to help the mobility of the visually impaired people is the guide dog. Thus, the law was enacted establishing the right of these people to remain in vehicles and public establishments accompanied by a guide dog. 
It is noticed that along the years there have been advances in legislation towards urban mobility. Recently, a law that determines the guidelines of the National Policy on Urban Mobility was enacted, whose goal is to improve access and mobility of people with disabilities in places of free movement. However, there has been limited progress to achieve these actions. It is through the compliance with the legislation, with publics policies and specifics programs to this population group that their rights will be respected and, consequently, changes in society will enable greater autonomy and participation in actions that favor the maintenance of health.

Most people with disabilities in Brazil, who are over fifteen years old are literate, corresponding to 81.7\%. However, out of these, approximately $61.1 \%$ have no education, or had incomplete elementary education. When compared to the population without physical or sensory disabilities, one observes a discrepancy of these data [4].

The law provides subsidies for the access of these people to the school environment. It is noticed that this access is often denied, as for example, in the study conducted with 235 people with disabilities, one found out that $50.2 \%$ of these had incomplete primary education and $18.3 \%$ were illiterate [11]. In this context, one notices the demand for education services of this population, however, the obstacles imposed on the school environment lead to the abandonment of the studies. According to the law, the modality of Special Education must be present in the educational system from preschool to supplementary education; it also encourages professional training, research and technology development for people with disabilities.

In the Sundsvall Statement, it is seen that education is fundamental to the occurrence of political, economic and social changes, and for creating an environment conducive to health, it is necessary the integration of all sectors, including education [1]. Access to information is one of the priorities defined in the Ottawa Charter, because it is through it that the population becomes empowered to choose a healthy lifestyle.

For the inclusion of deaf people in education services it was essential to create the law that recognizes the Brazilian Sign Language (Libras) as a means of expression and communication between deaf people, because it stimulates the spread of this language in educational institutions, emphasizing the importance of intersectionality to achieve health. Considering health promotion as a process of community empowerment and considering that social inclusion actions promote health, as it enables an increase in autonomy, responsibility for oneself, acquisition of skills and knowledge, with this law it is notorious the advancement within the health area for people with hearing impairment.

However, it is known that programs aimed to the deaf are still focused on oralism, an attempt to put these people into the hearing society. Thus, the use of hearing aids is highlighted [12]. A study highlights the rejection of this population in using these devices [13]. As the seven International Conferences on Health Promotion reaffirm that health is more than the adoption of a healthy lifestyle, it is a wellness in all the areas of life, the impositions of a hearing society and the difficulties in accepting this deaf culture can cause mental and emotional impact on people with hearing impairment, and hinder their access to health.

Article 4 of the same law addresses the inclusion in the curriculum of the teaching of Sign Language in the courses of speech therapy and teaching, leading these professionals to welcome deaf people effectively. It is an action of utmost importance for the health of this population, since speech therapists assist them to live with this disability, and teachers contribute to their education, one of the prerequisites to health, which has been debated since the first International Conference on Health Promotion.

The law regulated by Decree No. 5,626/05 establishes the teaching of Sign Language as an elective course for other courses of higher and professional education, establishes a maximum period of ten years after the publication of this decree for all the courses of speech therapy to offer this discipline, and ensures the right to health of people with hearing impairment. It is noticed an ambiguity present in this law, due to the following question: how will health professionals be able to ensure the right to health of deaf people without adequate communication between professionals and patients? It is suggested that the insertion of Sign Language in the curricula of health professionals becomes mandatory since this subject, as an elective one, is not attractive to students [14].

The main difficulty of deaf people is the communication, a fact that justifies the special attention of public policies to speech therapists, however, people with hearing disabilities have the same needs as anyone else. Therefore, immediate action is needed in the teaching of other professionals, such as doctors, nurses, dentists, psychologists, social workers, and others who have no training in their curricula Sign Language, causing numerous health problems to deaf people.

A study conducted in universities evaluated the curricular components of Nursing, Physiotherapy and Dentistry with the aim to investigate the teaching of Sign Language. One identified 16 Nursing Courses, ten Physio- 
therapy Courses and four Dentistry Courses, obtaining a quantitative of 30 courses, but only 24 out of these offered Sign Language (14 Nursing, seven Physiotherapy and three Dentistry courses). It is noteworthy that in 58\% of these institutions the teaching of sign language was an optional curricular component [15].

In relation to the visually impaired, the right to information has been guaranteed from the publication of the law establishing the printing of books in Braille. In the Declaration of Adelaide, originated in the II International Conference on Health Promotion in 1988, one notices the importance of public policies for the execution of the lines of action proposed in the Ottawa Charter [1]. In spite of the evolution of the rights of people with visual impairment, there is a difficulty in implementing these policies and for them to be effective it is fundamental a partnership between government and society.

For the achievement of universal education, through laws one launched the Complementation Program to Specialized Educational Services to People with Disabilities (PAED). Thus, people unable to study in regular education classes shall have the right to education guaranteed. To this end, the Federal Government and the Union guarantee the funding of special education in institutions. However, according to the law, these people should be inserted progressively into regular education.

In agreement with the V International Conference on Health Promotion held in Mexico in 2000, this law envisions equality so that different people with specific needs, should be treated as such. Allied to the perspective of education as an essential factor for achieving health, actions like this make it possible for the population to reach the highest level of health [1].

Failure to observe this law becomes clear in a qualitative study that points out the obstacles to the access of people with physical, visual and hearing impairment to education. The main complaints were related to the difficulties of communication between teachers and students, lack of books in Braille, Sign Language during classes and adequate physical structure. Respondents stated that these factors led to their exclusion from regular education [16].

Problems faced by people with hearing disabilities in the school environment could be solved with the presence of an interpreter of Sign Language in these institutions. Thus, there is a law enacted to support the work of these professionals, regulating the profession of translator and interpreter of Sign Language. Authors report the difficulties of deaf students to mingle in the regular school with hearing students, due to the difficulties in communicating with consequent exclusion from the group of people with disabilities. The presence of the translator and interpreter of Sign Language will extinguish those obstacles, since these professionals will act in the teaching of sign language for the hearing population [17].

Studies show social inequality experienced by people with disabilities, where most of them have low socioeconomic conditions [11]-[18]. It is known the influence that these conditions have on people's quality of life. The acquisition of good health conditions does not happen only through the availability of access to services. The sense of personal competence achieved through work associated with the income that it provides is intrinsically related to increased quality of life [18].

The Fourth International Conference on Health Promotion, which originated the Jakarta Declaration in 1997, emphasizes that poverty is the greatest threat to people's health, and income was classified as one of the prerequisites for the achievement of health [1].

Thinking about these social differences, the Brazilian government established a law that, besides contributing to health and education, benefits people's income, considering that it provides government support for vocational training of people with disabilities, makes the government responsible for the creation of vacancies and maintenance of jobs and encourages the creation of specific public policies that provide effective actions to their insertion in the labor market.

In the same law one launches the National Policy for the Integration of People with Disabilities, which establishes strategies that ensure social equity in the labor market. Aiming at the priorities in this field, they should have working hours adequate to their disability, flexible and appropriate schedule to their specific environment. From this policy, all the companies with 100 employees or more must compulsorily have between $2 \%$ - $5 \%$ of vacancies for beneficiaries of the Social Security Program or rehabilitated for the function, guaranteeing for them the right to apply for public examinations.

Working is a basic component of human needs that contributes to the increase in life expectancy with personnel and economic growth and it enables the inclusion of people in society, providing interpersonal relationships. Therefore, it is necessary to respect the differences [19].

There is a concern of the government to provide subsidies to people with disabilities, however only the crea- 
tion of laws does not guarantee employment and income to this population. For their rights to be ensured, the partnership of society is necessary as they are responsible for enforcing the laws. In this context, changes in concepts and prejudices, as well as structural and institutional changes are essential for the environment to be suitable. A study confirms through the testimonials of people with physical disabilities the difficulties in the law enforcement. Prejudice is highlighted among the major barriers, because society does not believe in the ability of these people to perform functions [19].

Regarding health, the issue of accessibility is still a challenge, since problems with the physical structure of health care services, as well as the unpreparedness of professionals to attend this population are characterized as obstacles. It is necessary awareness and commitment of governors, managers and professionals in compliance with the laws for the creation of favorable spaces to the health care of everyone.

By reducing architectural and furniture barriers it is evidenced less difficulty of people with disabilities to access health facilities, which contributes to the effective assistance through actions that promote health and improve their quality of life. The process of inclusion is a complex phenomenon that depends on changes in personal, social and environmental resources, because only the removal of physical barriers is not enough, being fundamental changes in the behavior of professionals to offer comprehensive care and quality health [20].

Given the above, during the First International Conference on Health Promotion, one has already observed concern about the fundamental conditions for obtaining health, and it can be changed through the influence of personal, social and environmental factors and to achieve it, people need to transform the environment in their favor [1].

It should be highlighted that the definition about favorable spaces to the process of health promotion was completed during the III International Conference on Health Promotion in Sweden in 1991, with the Declaration of Sundsvall. A favorable environment refers to all the physical and social elements around us, being represented by spaces where individuals live, such as their homes, workspace, leisure areas, health institutions. The terms environment and health are related interdependently, whose harmonious interaction is fundamental to the quality of people's lives. For the formation of healthy environments it is necessary to employ the principle of equity that ensures the inclusion of everyone in the access to health services and allocate resources to minority groups, such as people with disabilities [1].

Thus, it is pertinent to mention the law that establishes conditions assigned to the health sector to the support of people with disabilities, which aim to ensure access; appropriate treatment by suitable conduct; promote preventive actions; create networks of specialized rehabilitation and habilitation services and develop health programs aimed at this audience.

It is in this scenario of reformulation of health services and of construction of public policies for the promotion of health of people with disabilities that the importance of the Ottawa Charter is mentioned, which marks worldwide the growth of public health, having as the main focus the discussions about the reorientation of health services and an emphasis on actions that promote the empowerment of individuals in health care.

According to the Ottawa Charter, health systems must offer to the general public the highest level of health, and everyone (individuals, groups, professionals, managers and governors) have the responsibility to contribute to the promotion of health. The reorientation of health services aims to offer comprehensive care, including changes in the organizational structure, in the professional conduct and in the respect for the inherent characteristics of each individual. This attitude encourages the protection of individual needs, contributing to the achievement of a healthy lifestyle [1].

As a strategy that assists in the health promotion, leisure is considered a key element for citizenship and contributes to human emancipation. With the socio-political development of society, the conception of leisure that before was restricted to physical activity has become recognized as a right of individuals, as it improves their health conditions and is associated with their personal and social transformation [21]. Thus, leisure becomes a basic necessity and according to the usual practice it interferes positively or negatively in promoting health to the individuals' needs. In its various forms, leisure enables socialization, as well as physical, psychological and intellectual training, being a right of all the citizens.

With these considerations, it is known that everyone, without distinction, has the right to participate in leisure activities. Therefore, guaranteeing the access of people with disabilities to spaces that enable well-being, rest, entertainment, fun and culture allows their integration in society and human development. The Declaration of Adelaide brought contributions to the reduction of inequalities between population groups in social vulnerability when it encourages the creation of public policies aimed at increasing the accessibility of these people to goods 
and services that promote health [1]. Thus, areas or establishments offering leisure must provide access for people with disabilities to enjoy these services in an egalitarian way.

The defense of the creation of favorable conditions for the welfare of everyone for the scope of health promotion is also observed in the Declaration of Bogotá, originated at the International Conference on Health Promotion, held in Colombia in 1992, which proposed the development of public policies that ensure social fairness and the appearance of healthy environments that preserve life [1]. Study showed that people with disabilities point to a lack of accessibility to leisure area, considering disrespected by the population [16].

In accordance with the proposals established in these conferences, and recognizing the local situation, Brazilian laws make effective the rights of people with disabilities in the enjoyment of leisure practices in autonomous and equal conditions when they establish that concert areas, conference areas, classrooms, among others, should provide a space reserved for this public, allowing their easier access and circulation. In addition, another law requires that $5 \%$ of each ride in amusement parks is adapted for people with disabilities or reduced mobility.

Although these documents encourage the adequacy of leisure spaces to enable the inclusion of people with disabilities in health promotion activities, it has been noticed little contribution of society to meet these needs. A study has evidenced that people with disabilities point to a lack of accessibility to recreational areas, considering themselves disrespected by the population [16]. It is noticed that even with the determination of laws to reduce the difficulties of access, there is a noncompliance on the part of society, resulting in limitation of these people to participate in leisure activities, which impairs their quality of life. It is deal in implementing strategies of community awareness for affective reception of persons with disabilities in multiple spaces.

Based on the analysis of these laws, the results indicate that they converge to the support of concepts of access, accessible and accessibility, supporting the idea that these aspects contribute to the health promotion of people with disabilities. Although the concepts have similarities, the meanings are different and should be interpreted appropriately for an effective implementation of the elements and environments that promote health.

Access is understood as the act of arriving or getting into several places [22]. Accessible is the reach, action or use by any individual of urban spaces or facilities. And accessibility is the possibility of reaching, the perception and the understanding to use in a safe and autonomic way buildings, spaces and urban furniture [23].

Thus, all the people with or without disabilities, have equal rights and without discrimination to accessibility to basic services such as health, education, work and leisure, which are essential pillars for personal and social development, for encouraging the independence, inclusion in society and achievement of a healthier life. It is through the access to urban spaces and buildings that people with disabilities acquire the means for achieving health and improved quality of life [20].

\section{Conclusions}

Given the above, one realizes the importance of laws, public policies and programmers for ensuring the promotion of health for everyone. With the preparation of the Health Promotion Charts there was a rupture of old health conceptions, culminating in the consolidation of new practices that include all the population groups.

In the context of people with disabilities in Brazil, laws for health promotion propose the integration of citizens in several social sectors, and these rights are determined from the current legislation. Thus, it is clear that the progress in the formulation of laws aims at improving the health of this population by ensuring access to urban environments, health, income, education, transportation and leisure.

However, after reading the laws, it is noticed that their breach is present in Brazilian society. It can attribute to the failure and inefficiency in public policies and programs that implement the legislation. In this sense, a partnership between government and society to change this scenario and, consequently the achievement of health promotion for people with disabilities are extremely important.

\section{Funding}

Funded by the Fundação Cearense de Apoio ao Desenvolvimento Científico e Tecnológico.

\section{References}

[1] Ministério da Saúde (2002) Secretaria de Políticas de Saúde. Projeto Promoção da Saúde. As Cartas da Promoção da Saúde. Ministério da Saúde, Brasília.

[2] Buss, P.M. and Carvalho, A.I. (2009) Desenvolvimento da promoção da saúde no Brasil nos últimos vinte anos (1988- 
2008). Ciência \& Saúde Coletiva, 14, 2305-2316.

http://www.scielo.br/scielo.php?pid=S1413-81232009000600039\&script=sci_arttext

http://dx.doi.org/10.1590/S1413-81232009000600039

[3] Ministério da Saúde (1990) Lei n. 8080, de 19 de setembro de 1990. Dispõe sobre as condições para promoção, proteção e recuperação da saúde, organização e o funcionamento dos serviços correspondentes e dá outras providências. Ministério da Saúde, Brasília.

[4] Instituto Brasileiro de Geografia e Estatística (2010) Censo demográfico: Características gerais da população, religião e pessoas com deficiência. Instituto Brasileiro de Geografia e Estatística, Rio de Janeiro.

[5] Seron, B.B., Interdonato, G.C., Luiz Júnior, C.C. and Greguol, M. (2012) Prática de atividade física habitual entre adolescentes com deficiência visual. Revista Brasileira de Educação Física e Esporte, 26, 231-239.

http://www.scielo.br/pdf/rbefe/v26n2/06.pdf

[6] Castro, S.S., César, C.L.G., Carandina, L., Barros, M.B.A., Alves, M.C.G.P. and Goldbaum, M. (2008) Deficiência visual, auditiva e física: Prevalência e fatores associados em estudo de base populacional. Cadernos de Saúde Pública, 24, 1773-1782. http://www.scielo.br/scielo.php?script=sci_arttext\&pid=S0102-311X2008000800006 http://dx.doi.org/10.1590/S0102-311X2008000800006

[7] Secretaria Nacional de Promoção dos Direitos da Pessoa com Deficiência (2014) Legislação. Normas Constitucionais. http://www.pessoacomdeficiencia.gov.br/app/legislacao-0

[8] Cellard, A. (2008) A análise documental. In: Poupart, J., Deslauriers, J.P., Groulx, L.H., Laperriérri, A., Mayer, R. and Pires, A.P., Eds., A pesquisa qualitativa: Enfoques epistemológicos e metodológicos, Vozes, Petrópolis.

[9] Ministério da Saúde (2011) Decreto 7.612, de 17 de novembro de 2011. Plano Nacional dos Direitos da Pessoa com Deficiência-Viver sem Limite. Ministério da Saúde, Brasília.

[10] Amaral, F.L.J.S., Motta, M.H.A., Silva, L.P.G. and Alves, S.B. (2012) Fatores associados com a dificuldade no acesso de idosos com deficiência aos serviços de saúde. Ciência \& Saúde Coletiva, 17, 2991-3001.

http://www.scielo.br/scielo.php?script=sci_arttext\&pid=S1413-81232012001100016 http://dx.doi.org/10.1590/S1413-81232012001100016

[11] Souza, F.R. and Pimentel, A.M. (2012) Pessoas com deficiência: Entre necessidades e atenção à saúde. Cadernos de Terapia Ocupacional UFS, 20, 229-237.

http://www.cadernosdeterapiaocupacional.ufscar.br/index.php/cadernos/article/view/626 http://dx.doi.org/10.4322/cto.2012.024

[12] da Saúde, M. (2006) Secretária de Atenção à Saúde, Ministério da Saúde. Departamento de Ações Programáticas Estratégicas. Manual de legislação em saúde da pessoa com deficiência. Ministério da Saúde, Brasília.

[13] Nóbrega, J.D., Andrade, A.B., Pontes, R.J.S., Bosi, M.L.M. and Machado, M.M.T. (2012) Identity of the Deaf and Interventions in Health from the Perspective of a Community of Sign Language Users. Ciência \& Saúde Coletiva, 17, 671-679. http://www.scielo.br/scielo.php?pid=S1413-81232012000300013\&script=sci_arttext

[14] de Souza, M.T. and Porrozzi, R. (2009) Ensino de libras para os profissionais de saúde: Uma necessidade premente. Revita Práxis, 1, 43-46. http://web.unifoa.edu.br/praxis/numeros/02/43.pdf

[15] de Oliveira, Y.C.A., Costa, G.M.C., Coura, A.S., Cartaxo, R.O. and de França, I.S.X. (2012) Brazilian Sign Language in the Training of Nursing, Physiotherapy and Dentistry Professionals in the State of Paraíba, Brazil. Interface-Comunicação, Saúde, Educação, 16, 995-998.

http://www.scielo.br/scielo.php?script=sci_arttext\&pid=S1414-32832012000400011\&lng=en\&nrm=iso\&tlng=pt http://dx.doi.org/10.1590/S1414-32832012005000047

[16] da França, I.S.X. and Pagliuca, L.M.F. (2009) Inclusão social da pessoa com deficiência: Conquistas, desafios e implicações para a enfermagem. Revista da Escola de Enfermagem da USP, 43, 178-185. http://www.scielo.br/scielo.php?script=sci_arttext\&pid=S0080-62342009000100023 http://dx.doi.org/10.1590/S0080-62342009000100023

[17] Espote, R., Serralha, C.A. and Scorsolini-Comin, F. (2013) Inclusão de surdos: Revisão integrativa da literatura científica. Psico-USF, 18, 77-88. http://www.scielo.br/scielo.php?pid=S1413-82712013000100009\&script=sci arttext

[18] Mastropietro, A.P., Oliveira-Cardoso, E.A., Simões, B.P., Voltarelli, J.C. and Santos, M.A. (2010) Relação entre renda, trabalho e qualidade de vida de pacientes submetidos ao transplante de medula óssea. Revista Brasileira de Hematologia e Hemoterapia, 32, 102-107. http://www.scielo.br/scielo.php?script=sci arttext\&pid=S1516-84842010000200007 http://dx.doi.org/10.1590/S1516-84842010005000035

[19] Leal, D.R., de Mattos, G.D. and Fontana, R.T. (2013) Trabalhador com Deficiência Física: Fragilidades e agravos autorreferidos. Revista Brasileira de Enfermagem, 66, 59-66.

http://www.scielo.br/scielo.php?script=sci_arttext\&pid=S0034-71672013000100009

http://dx.doi.org/10.1590/S0034-71672013000100009 
[20] Pagliuca, L.M.F., Aragão, A.E.A. and Almeida, P.C. (2007) Acessibilidade e deficiência física: Identificação de barreiras arquitetônicas em áreas internas de hospitais de Sobral, Ceará. Revista da Escola de Enfermagem da USP, 41, 581588. http://www.scielo.br/scielo.php?script=sci_arttext\&pid=S0080-62342007000400007 http://dx.doi.org/10.1590/S0080-62342007000400007

[21] Bacheladenski, M.S. and Matiello Jr., E. (2010) Contribuições do campo crítico do lazer para a promoção da saúde. Ciência \& Saúde Coletiva, 15, 2569-2579. http://dx.doi.org/10.1590/S1413-81232010000500031

[22] Ferreira, A.B.H. (2009) Novo dicionário da língua portuguesa. Positivo, Curitiba.

[23] Associação Brasileira de Normas Técnicas (2004) NBR 9050: 2004. Acessibilidade a edificações, mobiliário, espaços e equipamentos urbanos. Associação Brasileira de Normas Técnicas, Rio de janeiro. 
Scientific Research Publishing (SCIRP) is one of the largest Open Access journal publishers. It is currently publishing more than 200 open access, online, peer-reviewed journals covering a wide range of academic disciplines. SCIRP serves the worldwide academic communities and contributes to the progress and application of science with its publication.

Other selected journals from SCIRP are listed as below. Submit your manuscript to us via either submit@scirp.org or Online Submission Portal.
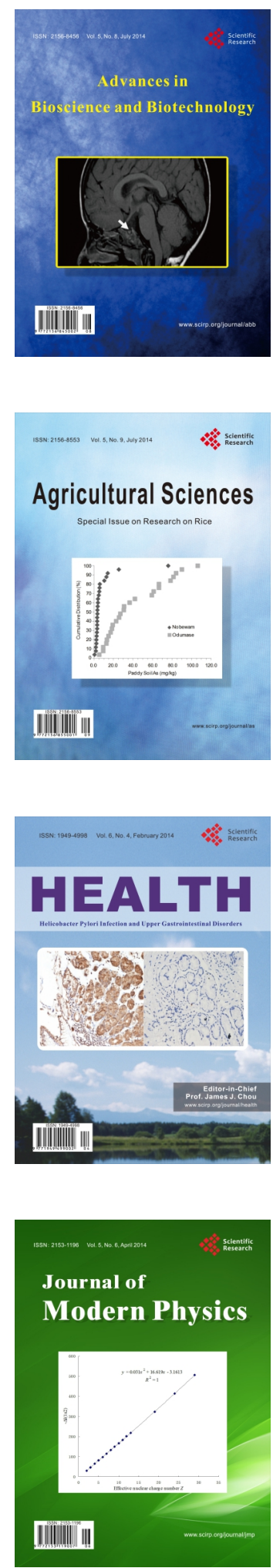
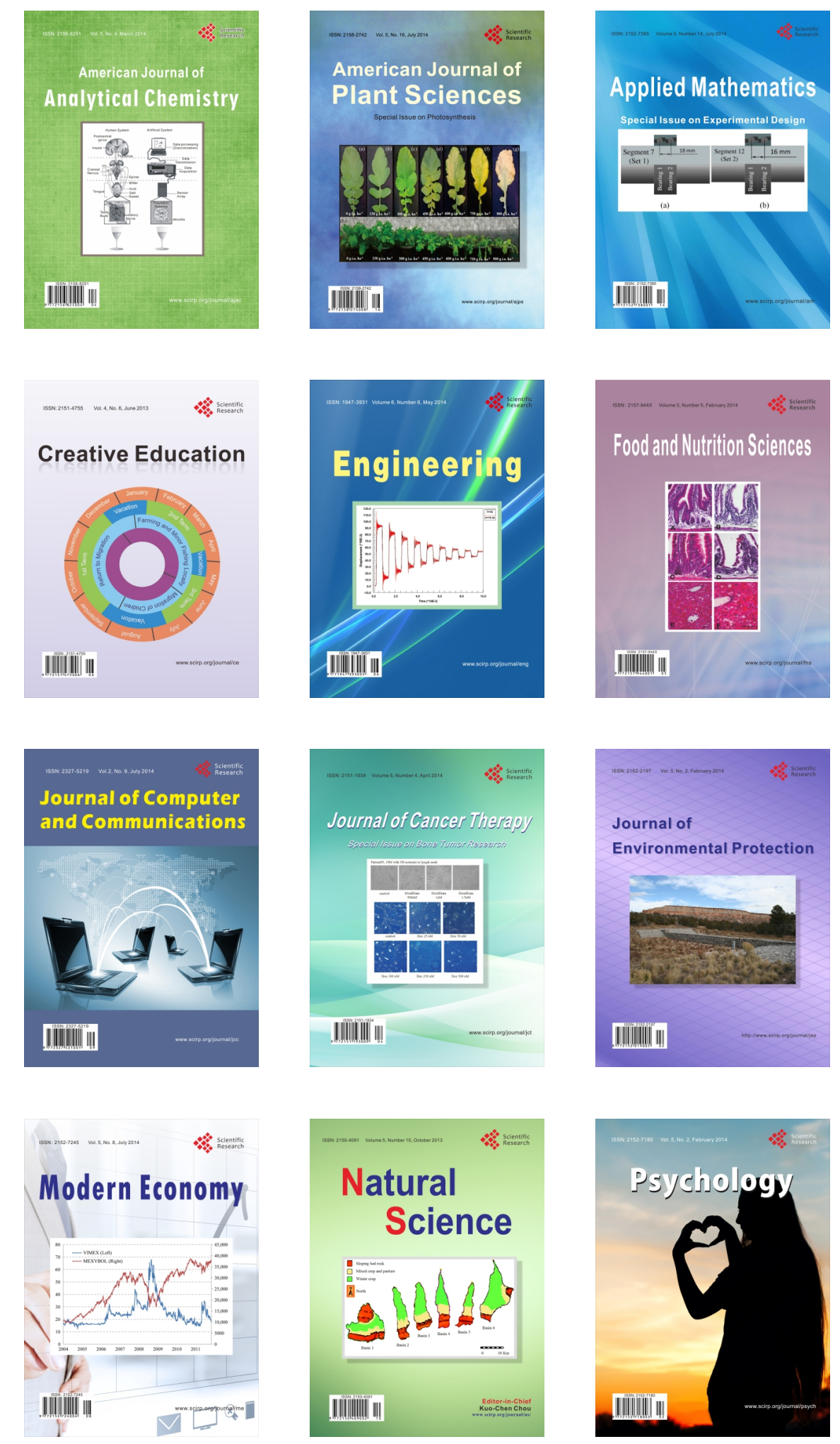